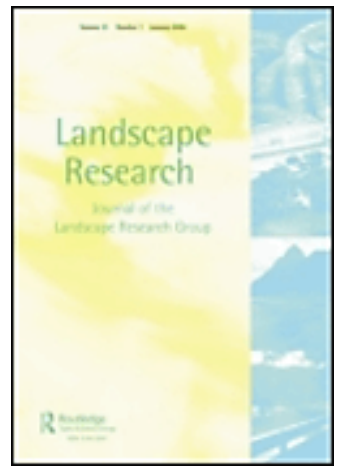

\title{
Vegetation series as a marker of interactions between rural settlements and landscape: new insights from the archaeological record in Central-Western Sicily
}

\begin{tabular}{|c|l|}
\hline Journal: & Landscape Research \\
\hline Manuscript ID & CLAR-2018-0162.R1 \\
\hline Manuscript Type: & Standard Research Paper \\
\hline Keywords: & $\begin{array}{l}\text { landscape ecology, landscape archaeology, vegetation mapping, site } \\
\text { catchment analysis, GIS }\end{array}$ \\
\hline & $\begin{array}{l}\text { Plant communities are complex and dynamic elements of the landscape, } \\
\text { intertwined with both natural factors and human activities. Vegetation } \\
\text { series reflect the environmental characteristics of the landscape, but also } \\
\text { the anthropic impact, one of the exogenous forces that most profoundly } \\
\text { affects the landscape formation process. This paper aims to investigate } \\
\text { the interactions between long-term human settlement catchment areas } \\
\text { and vegetation series. The case study area of the Sicani Mountains } \\
\text { (Central-Western Sicily) proved to be an ideal place to perform GIS- } \\
\text { based spatial analysis in order to compare a data set of rural } \\
\text { archaeological sites and land units created through the mapping of } \\
\text { vegetation series. The existence of a causal link between vegetation } \\
\text { series and human settlement patterns allows us, as well as future } \\
\text { researchers, to find new explanations for the formation of the } \\
\text { multifaceted Mediterranean rural landscape. }\end{array}$ \\
\hline
\end{tabular}

\section{SCHOLARONE" Manuscripts}




\title{
Vegetation series as a marker of interactions between rural settlements and landscape: new insights from the archaeological record in Central-Western Sicily
}

\author{
Giuseppe Bazan ${ }^{\mathrm{a}}$, Angelo Castrorao Barba ${ }^{\mathrm{b} *}$, Antonio Rotolo ${ }^{\mathrm{c}}$ and Pasquale \\ Marino $^{d}$
}

${ }^{a}$ Department of Biological, Chemical and Pharmaceutical Sciences and Technologies (STEBICEF), University of Palermo, via Archirafi 38, I 90123 - Palermo, Italy; Phone +39091238 91205; ORCiDs: orcid.org/0000-0002-4827-9579;

giuseppe.bazan@unipa.it

${ }^{b}$ Consejo Superior de Investigaciones Cientificas (CSIC), Escuela de Estudios Árabes (EEA), Carmen de los Mínimos - C/ Frailes de la Victoria 7, 18010-Granada Spain; Phone+34 958-222290 Ext. 22; ORCiDs: orcid.org/0000-0002-4360-4328; castroraobarba@eea.csic.es

cLudwig s.r.l.s., via Fiume 6, 90133 -Palermo, Italy; antonio@ludwig.guru

${ }^{d}$ Bona Furtuna LLC, P.O. Box 277, 95031 - Los Gatos CA,USA; bonafurtuna@gmail.com

* Corresponding author: Angelo Catrorao Barba

\begin{abstract}
Plant communities are complex and dynamic elements of the landscape, intertwined with both natural factors and human activities. Vegetation series reflect the environmental characteristics of the landscape, but also the anthropic impact, one of the exogenous forces that most profoundly affects the landscape formation process. This paper aims to investigate the interactions between long-term human settlement catchment areas and vegetation series. The case study area of the Sicani Mountains (Central-Western Sicily) proved to be an ideal place to perform GIS-based spatial analysis in order to
\end{abstract}


compare a data set of rural archaeological sites and land units created through the mapping of vegetation series. The existence of a causal link between vegetation series and human settlement patterns allows us, as well as future researchers, to find new explanations for the formation of the multifaceted Mediterranean rural landscape.

Keywords: landscape ecology, landscape archaeology, vegetation mapping, site catchment analysis, GIS, rural settlement patterns

\section{Introduction}

Vegetation plays a key role in the relationships among long-term human settlement patterns. Vegetation, like any other biological system, is dynamic. Plant communities change their floristic composition and structure in relatively short time periods in response to changes in both abiotic and biotic environmental factors. This process has been described for some time by ecologists as plant succession (Clements, 1928). The complex formed by plant communities settled in a specific territorial contexthomogeneous in their physical and biological characteristics - as the result of the plant succession process is called 'vegetation series' or sigmetum (Rivas-Martinez, 2007). Ecologically homogeneous areas, defined as tessellas by phytosociologists (RivasMartinez, 2005), present the same type of potential natural vegetation (Loidi \& Fernández-González, 2012) and share the spatial concept of the ecotope (Forman, 1995) or land unit.

The spatial distribution of various vegetation series is related to the ecological homogeneity generated by a hierarchical combination of climatic, lithological and geomorphological factors (Klijn \& Udo Haes, 1994). The classification of a landscape mosaic using vegetation series essentially follows a landscape ecology approach 
(Ingegnoli, 2015, p. 42) in order to define coherent and homogeneous geomorphologic, biogeographical and bioclimatic units. Nevertheless, the landscape of vegetation series is not static - that is, oriented only in relation to climate, lithology and geomorphology — because, within the vegetation mosaic, it is possible to observe the coexistence of different steps of the succession. The dynamics of succession (Figure 1) from mature vegetation (its climax represented by a woodland association) to various stages of plant succession (coppice, shrubland, grassland or grazing land, cropland) is related to the intensity of disturbance driven by exogenous human impact (Loidi, 2017, Chapter 3). Therefore, any change in a vegetation series reveals the typology and magnitude of human land use activities (i.e. agricultural and silvicultural activities and grazing). The mosaic of land units covered by different stages of a vegetation series hints at specific potentialities of landscape exploitation. For example, the presence of coppices indicates former silvicultural activities that have left their marks on the structure of the trees, while the physiognomy of plant communities from tree to shrub type may suggest the prolonged overexploitation of a forest to obtain firewood. Depending on the intensity of the processes, frequent grazing activities and fires - often used to foster herbaceous vegetation for forage - produce grasslands of perennial or annual plants. These semi-natural practices, when uncoupled from agricultural activities, give way to the commensal vegetation of the fields and the nitrophilousruderal vegetation of roadsides. In abandoned areas, the resilient processes of vegetation lead to the reappearance of secondary herbaceous and shrub formations and, in some cases, woods (Bazan, Castrorao Barba, Rotolo, \& Marino, 2018).

From this perspective, the analysis of the dynamics, locations and distributions of present-day land units of a vegetation series can be a fruitful tool for understanding the long-term relationships between plant communities and human settlements and their 
activities in a catchment area.

The aim of this paper is to test and evaluate — with a quantitative GIS-based approachthis type of relationship in a typical Mediterranean inland area, a sector of the Sicani Mountain district in Central-Western Sicily, a well-preserved landscape with an intense presence of long-term human occupation testified by various rural archaeological sites identified through a surface survey (Castrorao Barba et al., 2017).

\section{Study area}

The research area is located $8 \mathrm{~km}$ from Corleone in the inland area near Palermo, next to the SS188dir/c road in the direction of Campofiorito (Figure 2). The whole project area includes the areas of Contrada Castro, Contrada Giardinello and Contrada Valle Fredda, which goes up the slopes of Monte Barraù (or Monte Barracù), a Special Conservation Zone (ZCS) of the Monti Sicani district. The study covers a total surface area of 1464.46 hectares.

A high level of biodiversity is indicated by the presence of 502 taxa of vascular flora, 38 of which are endemic to Sicily (Cambria, Bazan \& Marino, 2015). Voucher specimens are stored in the Herbarium of Palermo Botanical Garden (PAL) and in the Herbarium of Bona Furtuna Farm (Corleone). In particular, some rare plants are reported, such as Nepeta apulei, Scorpiurus vermiculatus, Linaria chalepensis and Cephalaria syriaca, an uncommon archaeophyte in this region. A few remains of a holm oak wood, which once probably covered the area, are located on the southern slopes of Monte Barraù (Figure 3). These ecological characteristics of Contrada Castro and Contrada Giardinello (Figure 4) — particularly rich in freshwater springs —offer optimal conditions for agricultural and sylvo-pastoral activities and, hence, for historical human settlement. 
Like a typical Mediterranean countryside, this rural area has a long settlement occupation spanning from Prehistory to the Medieval period.

Within this huge district, our area was almost pristine from an archaeological point of view, and the only known archaeological site was a small, allegedly prehistoric, settlement located on the southern slopes of Rocche di Castro. The Alto Belice Corleonese district probably acted as a hinge between the southern and northern coasts of Sicily. It is likely that a network of roads between Palermo and Agrigento had already been established in the Roman period (the road Panormus-Agrigentum of the imperial cursus publicus), as became apparent in the Medieval and Modern periods. In fact, it is not a coincidence that the first historical mention of the area dates to the Middle Ages: more precisely, the toponym Barraù or Barracù is cited in the Jarida (Sicilian medieval land register) of Monreale dating to AD 1182. This toponym shows a clear Arabic origin, with a possible derivation from a former Greek toponym: Rā's Bū al-rakhū, latinized into caput Burrachu (Nef, 2011).

It is a quintessential Mediterranean inland environment, an area of Central-Western Sicily characterized by a long human occupation in a territory formed by the alternation of low hills or valley agricultural areas and mountainous slopes covered with grasslands for pastures. It is an ordinary Mediterranean landscape, but it is precisely for this reason that it serves as an ideal initial sample on which to test new interpretive paradigms.

\section{Methods}

\subsection{Mapping vegetation series}

In order to understand the relation between historical land use practices and the pattern of vegetation associations within a homogeneous ecological area (ecotope), we decided to conduct an accurate cartographic analysis (Figure 4). The first phase of analysis 
involved the study of plant communities that we carried out following Braun-Blanquet's classical methods (1928). Phytosociology provides a complete methodological framework for the survey, analysis, characterization an classification of plant communities (the plant associations). A recent methodological and conceptual overview is given by Biondi (2011). The field observations was carried out with a stratified random sampling by dividing the study area into different ecological homogeneous contexts and randomly sampling by relevés (Podani 2006). Phytosociological relevés has been made in plots of $100 \mathrm{~m}^{2}$. The syntaxonomical nomenclature at the levels of alliance, order and class follows the 'Prodrome of Italian Vegetation' (Biondi et al., 2014), and the taxonomic nomenclature has been harmonized according to Conti, Abbate, Alessandrini, \& Blasi (2005).

In order to spatialize these punctual vegetation data, a GIS-based vegetation map has been performed (Figure 5, phase 2). The cartographic analysis of the vegetation by GIS (ArcGIS-ESRI 10.2 software) was carried out through photo interpretation of rectified digital aerial images available from the national Geoportal (http://www.pcn.minambiente.it/GN/) and distributed by services such as Web Map Service (WMS), updated to 2012. In-depth interpretive studies were done by verifying and updating the data with 2016-Google Earth images.

According to the EUNIS habitat classification (Davies \& Moss, 2003), the images were manually digitized using ArcMap 10.2, with the individual cartographic units (polygons) having a minimum mappable area of $100 \mathrm{~m}^{2}$. For the definition of the vegetation map, we assigned a vegetation type (Syntaxon) discovered in the field to every cartographic unit (EUNIS Habitat).

To obtain a vegetation series map from the vegetation map, it was necessary to consider the hierarchical ecological factors which influence the distribution of vegetation, such 
as bioclimate, lithology and morphology (Figure 5, phase 3). The bioclimatic data is included in the dataset elaborated by Bazan, Marino, Guarino, Domina, \& Schicchi (2015). Data regarding the distribution of lithological types were extracted from the geological maps of the national CARG project (Di Stefano, Renda, Zarcone, Nigro, \& Cacciatore, 2013). Morphological information, expressed in slope classes, was processed by a Digital Terrain Model (DTM), derived from Light Detection and Ranging (LIDAR) data with a resolution of 2 m (flights from 2007-2008 and WCS service were furnished by the Region of Sicily, Department of Land and Environment, http://map.sitr.regione.sicilia.it/ArcGIS/services/DTM_2m/MapServer/WCSServer). For the identification of areas of homogeneous slope, the slope map was processed in ArcGIS with a Focal statistics algorithm, with a radius of $50 \mathrm{~m}$, making it possible to reclassify the raster of the slopes into two classes, $<20^{\circ}$ and $>20^{\circ}$. This range has been chosen because in Sicily the $20^{\circ}$ slope is the limit between agricultural systems and sylvo-pastoral systems (Bazan et al., 2009). From the overlay analysis of the ecological factors, were defined ecologically homogeneous areas, the ecotopes.

Ecotopes were matched with vegetation map to obtain an intermediate map of potential natural vegetation (Figure 5, phase 4). The vegetation series map was produced from a combination of the potential natural vegetation map and the vegetation map. In the legend, the vegetation types, grouped by vegetation series, are reported as both EUNIS habitats and sintaxa (Figure 6).

\subsection{Detecting the relationship between vegetation series and human settlement}

To frame the historical human occupation in the study area over the long-term, an archaeological systematic survey was carried out, covering a total surface area of 48.03 ha (27 fields were explored). 
The fieldwork was also supplemented by a study of written sources and the identification of sites in aerial photos from the 1950s to the present day (Bazan et al., 2018).

An approach to the relations between human occupation and the distribution of vegetation series requires a departure from a site-centric perspective in favour of a contextual one in which settlements are seen as more than just a use of the landscape but rather part of a system (Van Leusen, 2002). Each site, indeed, has an area of relevance tied to the availability of resources—above all, agricultural—for regular exploitation in a more or less intensive way (Vita-Finzi \& Higgis, 1970; Roper, 1979). One way to calculate the site catchment area is to identify the boundaries of an area walkable in a reasonable period of time to reach, work and use the resources of a portion of land around a given source site (Posluschny, 2009; Surface-Evans, 2012). In our case, the definition of the catchment areas is functional to their correlation with the surfaces occupied by different vegetation series so as to be able to analyse the mutual relationship between plant communities and the formation processes of different landscape types (i.e. agricultural, sylvo-pastoral, forest). Theoretical models have approximated that traditional tillage farming practices are generally carried out within a maximum distance of $2.5 \mathrm{~km}$ from a site, walkable in about 30 minutes, while the area for the cultivation and exploitation of forest resources extends up to $5 \mathrm{~km}$, that is, up to 1 hour of walking (Bintliff, 1999).

Thus, we have utilized a GIS procedure (Rotolo, 2016; Becker, de Andrés-Herrero, Willmes, Weniger, \& Bareth, 2017) as a method to estimate the area walkable in half an hour and one hour around each site, by creating a cost surface based on Tobler's Hiking Function (Tobler, 1993) that defines the traveling speed for every degree of slope (0 slope is about $5.037 \mathrm{~km} / \mathrm{h})$. The raster of the slopes derived from DTM Lidar ( $2 \mathrm{~m}$ 
resolution) was transformed into radians ( 1 radian $=57.29577951$ degrees $)$ and reclassified with an algebraic map operation, according to Tobler's Hiking Function in the version modified by Tripcevich (2006), in order to obtain values relative to the time (h) to cross a cell ( $2 \mathrm{~m}$ in our case) characterized by a certain slope: $\left[0.000166666 *(\operatorname{Exp}(3.5 *(\mathrm{Abs}(\text { slope in radians })+0.05))]^{*} 2\right.$. The result was used as raster friction for the ArcGIS Cost Distance analysis of each site. In this way, it was possible to carry out two calculations of the rasters of cost distance-with ('rasters of cost distance' $<=0.5,1.0$ ), and with ('rasters of cost distance' $<=1,1.0$ ) — to obtain an isochor around every site equivalent to the surface walkable in 30 minutes and 1 hour. With ArcGIS geoprocessing tool "clips" between these surfaces and the map of the vegetation series, it was possible to extract a subset of map for quantifying in percentage the extension of each series within the various catchment areas.

To balance and compare our results, we selected a control area located about $15 \mathrm{~km} \mathrm{SW}$ of the area of study, in the district of Contessa Entellina, having similar vegetation series as well as a long human occupation over the centuries. This area has been deeply studied by several detailed archaeological surveys that have detected many rural sites from Prehistory to the Medieval period (Corretti, Facella, Gargini, Michelini, \& Vaggioli, 2006). The chosen control area covered the same extension as our study area in Corleone. We replicated the same GIS spatial analysis on a group of archaeological sites and vegetation series, mapped with the above-described methodology, in the control area of Contessa Entellina. In order to compare the different catchment areas in term of the intersection of vegetation series, a cluster analysis, using a hierarchical classification methods, was performed in R software (http://R-project.org/). The hierarchical clustering has been based on UPGMA with Euclidian distance as similarity coefficient one of most often used clustering algorithms in ecological analysis. 


\section{Results}

\subsection{Modelling landscape formation processes through the vegetation series}

The hierarchical land classification and mapping (Figure 5, phase 3) identified four different ecotopes in the study area and defined them in relation to two main bioclimatic belts (Mesomediterranean, Supramediterranean), two lithological complexes (Carbonate and Clays) and two morphological types (Hilly and Mountainous).

The ecotopes correspond to four different vegetation series which included the respective stages of current vegetation (Figure 6):

1. Mesomediterranean, Sicilian, holm oak series (Ampelodesmo mauritanici-Querco ilicis sigmetum); $19.5 \%$ of the total surface area.

2. Thermo-mesomediterranean, Tyrrhenian, downy oak series (Oleo oleasterQuerco virgilianae sigmetum); $68.1 \%$ of the total surface area.

3. Supramediterranean, Sicilian, holm oak series (Sorbo torminalis-Querco ilicis sigmetum); $0.4 \%$ of the total surface area.

4. Supramediterranean, Sicilian, downy oak series (Sorbo torminalis-Querco virgilianae sigmetum); $12 \%$ of the total surface area.

The first vegetation series is found in the sub-mountain belt, at altitudes between 500 and approximately $1300 \mathrm{~m}$ a.s.l., where it prefers shady and humid steep slopes, with predominant western/southwestern exposure and soils rich in detrital material, produced by erosion and landslides. The mature formation consists of a coppiced holm oak wood (Ampelodesmo mauritanici-Quercetum ilicis) (Gianguzzi, Cuttonaro, Cusimano, \& Romano, 2016). This community is characterized by a closed woody layer of Quercus ilex, 5-10 m high, which also includes Fraxinus ornus and Quercus virgiliana. Evidence of the wood's degradation due to cutting or fire is indicated by the presence of 
Prunus spinosa shrubbery (Euphorbio characiae-Prunetum spinosae). The community is co-dominated by other Rosaceae species (Crataegus monogyna, Rosa canina, Pyrus spinosa) and thorny-lianous entities (Asparagus acutifolius, Clematis vitalba, Lonicera etrusca, Rubia peregrina)

The development of animal farming practices is the main cause of this series's passage to a further stage of degradation, leading to the formation of secondary Ampelodesmos mauritanicus grassland (Helictotricho convoluti-Ampelodesmetum mauritanici). This grassland is physiognomically characterized by the dominance of Diss, which is usually mixed with other Poaceae, such as Helictotrichon convolutum, Avenula cincinnata and Melica ciliata.

Lithosoils, derived from human-induced erosion, are colonized by erbaceouschasmophilous coenoses (Carduncello-Thymetum spinulosi) on calcareous substrata, or dry grassland (Hyparrhenietum hirto-pubescentis) on clayey soils. In areas where grazing has been more intense or which have been abandoned for agricultural purposes, the vegetation degrades towards Mediterranean xeric grassland, often dominated by Ferula communis.

The second series (Oleo oleaster-Querco virgilianae sigmetum) is widespread over clayey substrates (sometimes with a rocky matrix originating from limestone) with hilly morphologies, in stations with a certain environmental xericity (average annual rainfall from $500 \mathrm{~mm}$ to $800 \mathrm{~mm}$ ). The mature formation consists of small remnants of oak woods (Oleo oleaster-Quercetum virgilianae) (Gianguzzi, Papini, \& Cusimano, 2016) near waterways (the Giardinello and Batticano rivers). This series occupies areas of landscape with a strong agricultural potential that have therefore been deeply affected by intensive cultivation (e.g. wheat, vineyards, olive trees and, to a lesser extent, fruit trees). 
In marginal areas (escarpments and steep slopes), hardly exploitable for agricultural uses, fires and grazing have triggered degradation processes that normally lead to the establishment of shrubby communities dominated by Rosaceae species (Roso corymbiferae-Rubetum ulmifolii) and, subsequently, Ampelodesmos mauritanicus grassland (Helictotricho convoluti-Ampelodesmetum mauritanici). In abandoned fields, the initial stage of the Oleo oleaster-Querco virgilianae sigmetum is represented by Mediterranean grassland, dominated by Arundo collina (Euphorbio ceratocarpaeArundinetum collinae). This association, dynamically connected with the synanthropic vegetation, grows on clayey stands, characterized by deep soils, where the community is floristically quite poor.

During the last fifty years, abandoned areas have also been re-colonized by shrubs of Sicilian sumac (Rhus coriaria) whose abundance testifies to the ancient and widespread cultivation of this species in the area. The presence of numerous surface springs has fostered the establishment of Ulmus woodlands, a dense woodland typical of depressed surfaces with evolved soils that maintain a certain amount of humidity even during summer. Ulmus canescens is accompanied by a few other species, including Euphorbia characias, Rosa canina, Rubus ulmifolius, Pyrus spinosa and Anagyris foetida. At the highest elevations within the Supramediterranean bioclimatic belt, characterized by carbonate lithosoils, the Sorbo torminalis-Querco ilicis sigmetum finds its ideal ecological conditions. The series head of this vegetation is a Quercus ilex woody community, 5-10 m high, with a floristic cortege much more mesophilous than Ampelodesmo-Quercetum ilicis (Gianguzzi et al., 2016). The stages of degradation of the wood due to fire and grazing are a shrubby community ascribed to Roso siculaePrunetum spinosae and Mediterranean-montane grassland dominated by Cachrys ferulacea (Cachryetum ferulaceae). 
The Sorbo torminalis-Querco virgilianae sigmetum is found in areas with deeper soils and softer landforms above 1000 meters of elevation. In addition, the high agricultural potential of this ecological context has led to the almost total disappearance of downy oak woodlands, which have been replaced by mountain crops. The residual forest vegetation consists of a woody community with a dominance of Quercus virgiliana, with Quercus ilex, Fraxinus ornus and, in the undergrowth, Sorbus torminalis. The secondary aspects which have developed where cultivation has been abandoned consist of mountain shrubs with Crataegus laciniata, along with Rosa canina, Acer campestre, Pyrus spinosa, Rosa sicula, Rubus ulmifolius, (Crategetum laciniatae). In contrast, in areas where grazing activity continues, mountain grasslands are found which are characterized by the presence of mesophilic species such as Cynosurus cristatus, Lolium perenne, Leontodon siculus, Erysimum bonannianum, (CynosuroLeontodontetum siculi).

The majority of the control area of Contessa Entellina is covered by the Oleo oleasterQuerco virgilianae sigmetum, and the Ampelodesmo mauritanici-Quercetum ilicis sigmetum is widespread on the north-eastern side.

This composition of plant communities in the two areas indicates similar ecological conditions in term of climate, lithology and geomorphology.

\subsection{The mutual influence between vegetation series and settlement patterns}

The archaeological survey led to the identification of evidence of 16 sites of human occupation, dating from the Protohistoric to the Medieval to the Modern period (Castrorao Barba et. al., 2017). In particular, we identified and delimited 12 areas of pottery concentration and 4 areas with architectural remains of shepherding activities during the pre-industrial period, including a large enclosure made of dry limestone walls with rubble filling, locally called mannare, and some circular shepherd shelters 
(pagghiari). Fieldwork data has been combined with the aerial photo interpretation to detect other structures related to pastoral activities, old homesteads of the type called masserie (dating back to the $19^{\text {th }}$ century), which were landlord residences and places for the storage of agro-pastoral surplus. In total, 25 sites have been identified (Figure 7a) and subdivided as follows:

- Protohistoric, 2800-2300 BC / 1800-1200 BC (pottery): Site number 6, 7, 8, 9;

- Classical, 600-400 BC (pottery): Site number 16;

- Medieval, 900-1200 AD: Site number 1, 2, 3, 4, 5;

- Late Modern, 1800-1900 AD (pottery): Site number 11, 12;

- Late Modern / Early Contemporary, 1800-1950 AD (shepherd structures): Site number $10,13,14,15,18,19,20,23,24$;

- Late Modern / Early Contemporary, 1700-1950 AD (agricultural buildings), Masseria Barraù, Masseria Giardinello, Masseria Spatafora, Masseria San Giovanni: Site number $17,21,22,25$.

The group of sites (Corretti et al., 2006) selected in the control area of Contessa Entellina (Figure 7b) consists of:

- Prehistoric sites: Site number 26, 27;

- Prehistoric, Medieval sites: Site number: 28;

- Late Archaic, Classical site: Site number 33;

- Late Archaic, Classical, Hellenistic sites: Site number 29, 30, 34

- Late Archaic, Classical, Hellenistic, Medieval site: Site number 31;

- Medieval sites: Site number 32, 35.

The data on the spatial relationships between the catchment site areas walkable in 30 minutes and 1 hour and the surfaces occupied by different vegetation series indicate the mutual influence between settlement choices and the use of local resources and the 
specific ecological characteristics of the area (see Table 1 and Figure 8).

For the most part, the catchment areas of the sites from the northwestern area of the study cover the zones linked to the Oleo oleaster-Querco virgilianae sigmetum / Sorbo torminalis-Querco virgilianae sigmetum, with very high average values of $91.5 \%$ (30 $\min )-90.5 \%(1 \mathrm{~h})$ for the protohistoric sites, $94.4 \%(30 \mathrm{~min})-90 \%(1 \mathrm{~h})$ for the medieval sites, and $96.7 \%(30 \mathrm{~min})-91.2 \%(1 \mathrm{~h})$ for the modern sites. On the contrary, the Ampelodesmo mauritanici-Querco ilicis sigmetum has catchment areas with very low average values: $8.1 \%(30 \mathrm{~min})-9.5 \%(1 \mathrm{~h})$ for the protohistoric sites, $5.1 \%(30$ $\min )-10 \%(1 \mathrm{~h})$ for the medieval sites and $2.9 \%(30 \mathrm{~min})-8.5 \%(1 \mathrm{~h})$ for the modern sites.

The tendency is rather different in the catchment areas of the sites related to shepherding activity (mannare and pagghiari), located in the southern and eastern areas of the study. At these sites, although the Oleo oleaster-Querco virgilianae sigmetum / Sorbo torminalis-Querco virgilianae sigmetum are predominant, they occupy a smaller portion of the catchment areas for an average value of $79.7 \%(30 \mathrm{~min})-74.9 \%(1 \mathrm{~h})$, with higher average values $(20 \%, 30 \mathrm{~min}-24.7 \%, 1 \mathrm{~h})$ for the surfaces covered by the Ampelodesmo mauritanici-Querco ilicis sigmetum series.

The only exceptions are site 10 (mannara) in the northern part of the area, with a catchment area averaging $94.7 \%(30 \mathrm{~min})-89.9 \%(1 \mathrm{~h})$ for the Oleo oleaster-Querco virgilianae sigmetum, and the site from the classical epoch $\left(6^{\text {th }}-5^{\text {th }}\right.$ century $\left.\mathrm{BC}\right)$, located on the plateau of a small hill in the southeast, whose catchment area includes a slightly lower percentage of the Oleo oleaster-Querco virgilianae sigmetum $(73.5 \%, 30 \mathrm{~min}-$ $71.7 \%, 1 \mathrm{~h}$ ) compared to that observed for the other sites with settlements.

In 8 of 10 sites in the control area $(26,27,28,29,30,31,34,35)$, an average of $98.1 \%$ (30 $\mathrm{min}$ ) and $97.7 \%$ (1 h) catchment areas were covered with the Oleo oleaster-Querco 
virgilianae sigmetum. Only sites 32 and 33 show a larger surface, in comparison to the trend observed in the other 8 sites, with an average of $34.3 \%(30 \mathrm{~min})$ and $14.8 \%(1 \mathrm{~h})$ catchment areas occupied by the Ampelodesmo mauritanici-Querco ilicis sigmetum.

\section{Discussion}

The reading of the vegetation series has enabled us to frame some of the characteristics of the double dimension of the landscape, both temporal and spatial. The role of human impact over time and the formation of a layered landscape are visible in the various steps in the succession of each series. The space (horizontal) is linked to the dislocation of plant communities within the environmental diversity of the area.

The various stages in the succession of the holm oak series (Ampelodesmo mauritaniciQuerco ilicis sigmetum) give us an interpretive image of the morphogenetic processes of the sylvo-pastoral landscape (Figure 1). The steep slopes, characterized by shallow soils, in fact, provide the ideal ecological conditions for the development of holm oak woods, whose disappearance or rarefaction is linked to multiple forest uses, from fuel to raw materials for building and tool-making. The degraded forms of shrubbery (Euphorbio characiae-Prunetum spinosae) and grasslands (Helictotricho convolutiAmpelodesmetum mauritanici, Carduncello-Thymetum spinulosi) are derived from harvesting in holm oak forests and wildfires. The presence of shrubs, rich in thorny species, and secondary grasslands with many plants which are unpalatable for livestock, such as Asphodelus ramosus, Asphodeline lutea, Bituminaria bituminosa, indicate the prolonged impact of grazing on the plant community (Papanastasis, Kyriakakis, \& Kazakis, 2002). The selective action exerted by grazing animals has favoured the growth of species with fewer palatable characteristics, yet another indicator of the emergence of pastoralism. The same considerations are also valid for the holm oak series at high elevations (Sorbo torminalis-Querco ilicis sigmetum), where the structure 
and floristic composition of secondary formations have been shaped by long-term grazing use.

The extension of the holm oak series is a marker of the activity of forest resource exploitation, farming and pastoral practices, but this is not a deterministic axiom because, in certain historical periods, the area of the holm oak series was subject to man-made changes for other purposes. The construction of terraces is a clear example of how modifying the morphology, through the construction of retaining walls to increase the thickness of the soil, has also favoured agricultural cultivation on the hillside slopes characteristic of the holm oak series. Moreover, none of these processes has a linear progression towards a hypothetical 'climax' of productivity, but is rather subject, in the flow of time, to instances of 'regression', that is, of returning to the different states of succession, as in the case of the abandonment of terrace cultivation and the return of grasslands for grazing.

On the other hand, the trajectory of the downy oak series (Oleo oleaster-Querco virgilianae sigmetum and Sorbo torminalis-Querco virgilianae sigmetum) is quite different as it is related to the way the very deep, fertile soil was, over the long term, stripped of its forest cover in order to create the best fields possible for agricultural purposes (Figure 1). But this is not a univocal and deterministic process either because, due to variations in historical and socio-economic conditions, the spaces of the downy oak series could have also undergone the processes of cultivation abandonment and a consequential shift to other types of vegetation, from shrubs and pastures to the formation of wooded areas. The presence of shrubs of Sicilian sumac (Rhus coriaria) is, as previously noted, an indicator of prior cultivation, as are grasslands dominated by Arundo collina (Euphorbio ceratocarpae-Arundinetum collinae), which are strictly correlated to abandoned arable land. In addition, even shrubs of thorny Rosaceae (Roso 
corymbiferae-Rubetum ulmifolii, Crategetum laciniatae) and pasture grasslands (Helictotricho convoluti-Ampelodesmetum mauritanici, Cynosuro-Leontodontetum siculi) are the products of fires and grazing activity practiced in small marginal areas within agricultural systems.

This close relationship between vegetation series and an area's potential suitability for agricultural or grazing is an element that also allows us to read those phenomena in which these linkages have produced opposite situations, such as the previously described example of terracing, or of an oak forest being conserved around fully cultivated areas, which may indicate the persistence of particular constraints (i.e. public property or community use rights) which, over time, prevented its complete deforestation.

Vegetation series tell us a story in which humans acted as the 'super-actors' in these ecological interactions. The observation of vegetation series makes human impact on the landscape visible and reveals the traces and signs of certain segments of the driving forces that generated these changes (Bürgi, Hersperger, \& Schneeberger, 2004): the accumulation of socio-economic and cultural systems (innovations, long-term processes, resilience) that initiated a dynamic relationship with the environment and its precious natural resources.

The mutual interaction between human settlements and vegetation series finds a corresponding representation in the spatial localization of 1-hour walking catchment areas for different types of sites. The sites oriented mostly toward agriculture are located in the core of the downy oak series, and the places related to transhumance and pastoral practices reveal a closer proximity to the holm oak series. Furthermore, the half-hour walkable catchment areas are almost completely within the space covered by the downy oak series, and only in the 1-hour zones have some parts arrived at the holm 
oak series. These relationships fit well with Bintliff's hypothesis (1999) about the dimensions of site catchment areas in the Mediterranean countryside, where the daily access time for reaching the fields for ploughing is estimated at half an hour of walking, and the time for reaching cattle/sheep pastures or exploiting forest resources is estimated at one hour. Moreover, in this perspective, the role of the downy oak series in the formation of agricultural landscapes and of the holm oak series for sylvo-pastoral and forest landscapes is emphasized.

The formation of settlement patterns is not only driven by a rigid deterministic relationship between land-use suitability and landscape characteristics. Different typologies of sites (e.g. forts/military posts or religious centres), the influence of geopolitical factors (e.g. borders), administrative factors (e.g. land ownership) and connectivity factors (e.g. road networks) play a role in the definition of sites location and settlements network. A perspective on and analysis of the landscape through spatial interactions between settlement locations and vegetation series is also useful in detecting certain anomalies that go beyond a static determinism. For example, the 'anomalies' of the two sites $(32,33)$ located in the core of holm oak series may be explained following the interpretation already made by the archaeologist who connected them to a road path between the valley floor and Mount Carrubba (Corretti et al., 2006). The comparison of two similar areas has been a test of vegetation series/site-catchment area relationships. The cluster analysis shows a similarity between the case study area and the control area. The cluster dendrogram (Figure 9) depicts a general framework dominated by a large group of sites (a) with a catchment area mainly covering the downy oak series (more suitable for agriculture) and another small group (b) in which the catchment area also presented a relevant connection with the holm oak series (more suitable for sylvo-pastoral practices) — but always less in absolute value then the downy 
oak series. A third cluster (c) indicates sites located in the Supramediterranean bioclimatic belt.

It is thus evident that there is a causal link between the vegetation series and the actions that humans perform in and on the landscape. This relationship is easily noticeable in the short term, but it becomes more and more subtle and difficult to interpret over the long term. This difficulty is due to the fact that, on the one hand, anthropic activity varies over time, both in intensity as well as type, and, on the other hand, vegetation responds by adopting resilient behaviours to external stimuli. The more articulated this back and forth process between anthropic phenomena (e.g. fire, deforestation, agriculture, herding) and renaturalisation (when the human influence diminishes) is, the more uncertain the inferences that we are capable of making about the historical evolution of the landscape, starting from vegetation series.

The mosaic of plant relationships is precisely this uncertain mingling in time due to human-environment interactions. The analysis of the territory from a syndynamic or, more precisely, a synphytosociological point of view, instead allows us to change perspective and observe the mosaic tiles according to the possibilities of different landuse trajectories, according to a non-deterministic dynamism in which the passages between the various stages of succession are indicators of the formative processes of rural Mediterranean landscapes.

\section{Funding}

This work was supported by the 'Harvesting Memories: Ecology and Archaeology of Monti Sicani landscapes (Central-Western Sicily)' project, funded by Bona Furtuna, LLC (Project Coordinator: G. Bazan; scientific direction of archaeological survey: S. Vassallo).

\section{Acknowledgements}

We would like to express our gratitude to Steve Luczo, owner of Bona Furtuna LLC, 
who entirely supported and funded the project 'Harvesting Memories: Ecology and Archaeology of Monti Sicani landscapes (Central-Western Sicily)’.

\section{References}

Bazan, G., Baiamonte, G., Marino, P. (2009, June) Land forms, land-use and landscapes in Sicily. Paper presented at International Congress of SISV, FIP. Cagliari (Italy).

Bazan, G., Castrorao Barba, A., Rotolo, A. \& Marino, P. (2018). Geobotanical approach to detect land-use change of a Mediterranean landscape: a case study in CentralWestern Sicily. GeoJournal, 2018, 1-17. doi: https://doi.org/10.1007/s10708018-9892-1

Bazan, G., Marino, P., Guarino, R., Domina, G., \& Schicchi, R. (2015). Bioclimatology and vegetation series in Sicily: A geostatistical approach. Annales Botanici Fennici, 52(1-2), pp. 1-18.

Becker, D., de Andrés-Herrero, M., Willmes, C., Weniger, G. C., \& Bareth, G. (2017). Investigating the Influence of Different DEMs on GIS-Based Cost Distance Modeling for Site Catchment Analysis of Prehistoric Sites in Andalusia. ISPRS International Journal of Geo-Information, 6(2), 36, pp. 1-28. doi: 10.3390/ijgi6020036

Bintliff, J. (1999). Settlement and Territory. In G. Barker (Ed.), Companion Encyclopedia of Archaeology (Vol. 1, pp. 505-545), London and New York: Routledge. Retrieved from http://routledgeonline.com/history/Book.aspx?id=w404

Biondi, E. (2011). Phytosociology today: Methodological and conceptual evolution, Plant Biosystems, 145: 19-29. doi: 10.1080/11263504.2011.602748 
Biondi, E., Blasi, C., Allegrezza, M., Anzellotti, I., Azzella, M. M., Carli, E., ... Galdenzi, D. (2014). Plant communities of Italy: the vegetation prodrome. Plant Biosystems, 148(4), 728-814. doi: 10.1080/11263504.2014.948527

Braun-Blanquet, J. (1928). Pflanzensoziologie: Grundzüge der Vegetationskunde [Phytosociology: basic principles of vegetation science]. Biologische Studienbücher 7. Berlin: Springer. Retrieved from http://www.springer.com/us/book/9783709181119

Bürgi, M., Hersperger, A. M., \& Schneeberger, N. (2004). Driving forces of landscape change-current and new directions. Landscape ecology, 19(8), 857-868. doi: $10.1007 / \mathrm{s} 10980-005-0245-3$

Cambria, S., Bazan, G. \& Marino, P. (2015, September). Flora e vegetazione della Valle di Castro e di Monte Barraù (Sicilia centro-occidentale). Poster presented at the 49th Congresso della Società Italiana di Scienza della Vegetazione. Ancona (Italy).

Castrorao Barba, A., Rotolo, A., Bazan, G., Marino, P., \& Vassallo, S. (2017). Longterm human occupation of a rural landscape in Central-Western Sicily (Castro/Giardinello Valley and Mt Barraù): Harvesting Memories project case study. ArkeoGazte. Revista de arqueología - Arkelogia aldizkaria, 7, 175-192.

Clements, F. E. (1925). Plant Succession and Indicators: A definitive edition of Plant Succession and Plant Indicators. New York: The H. W. Wilson Company.

Conti F., Abbate G., Alessandrini A., \& Blasi C. (2005). An annotated checklist of the Italian vascular flora. Roma: Palombi Editori.

Corretti, A., Facella, A., Gargini, M., Michelini, C., \& Vaggioli, M. A. (2006). Per una carta storico-archeologica del Comune di Contessa Entellina: dati archeologici preliminari (1998-2002) [For an historical-archaeological map of Contessa 
Entellina municipality: preliminary archaeological data (1998-2002)], in Atti delle V giornate internazionali di studi sull'area elima e la Sicilia occidentale nel contesto mediterraneo [Proceedings of the $5^{\text {th }}$ conference of international studies on the Elymian area and the western Sicily in Mediterranean context] (Erice 2003), Pisa 2006, 561-593.

Davies C. E. \& Moss D. (2003). EUNIS habitat classification, August 2003. European Topic Centre on Nature Protection and Biodiversity, Paris

Di Stefano, P., Renda, P., Zarcone, Nigro, F., \& Cacciatore, M. S. (Eds.). (2013). Foglio 619 Santa Margherita Belice: Note illustrative della Carta Geologica d'Italia alla scala 1:50.000 [Foglio 619 Santa Margherita Belice: Illustrative note of the Carta Geologica of Italy at 1:50.000 scale]. Roma: System. Retrieved from http://www.isprambiente.gov.it/Media/carg/note_illustrative/619_S_Margherita _di_Belice.pdf

Forman, R. T. T. (1995). Land Mosaics: The Ecology of Landscapes and Regions. Cambridge: Cambridge university press. Retrieved from http://www.cambridge.org/gb/academic/subjects/life-sciences/ecology-andconservation/land-mosaics-ecology-landscapes-andregions? format $=$ PB\&isbn $=9780521479806$

Gianguzzi, L., Cuttonaro, P., Cusimano, D., \& Romano, S. (2016). Contribution to the phytosociological characterization of the forest vegetation of the Sicani Mountains (inland of north-western Sicily). Plant Sociology, 53(1), 5-43. doi: $10.7338 /$ pls2016531/02

Gianguzzi, L., Papini, F., \& Cusimano, D. (2016). Phytosociological survey vegetation map of Sicily (Mediterranean region). Journal of Maps, 12(5), 845-851. doi: $10.1080 / 17445647.2015 .1094969$ 
Ingegnoli, V. (2015). Landscape Bionomics Biological-Integrated Landscape Ecology. Milan Heidelberg New York Dordrecht London: Springer. doi: 10.1007/978-88$470-5226-0$

Klijn, F. \& Udo Haes, H. A. (1994). A hierarchical approach to ecosystems and its implications for ecological land classification. Landscape ecology, 9.2, 89-104. doi: 10.1007/BF00124376

Loidi, J. (2017). Dynamism in Vegetation. Vegetation Changes on a Short Time Scale. In J. Loidi (Ed.), The Vegetation of the Iberian Peninsula (Vol. 1, pp. 81-99). Cham: Springer. doi: 10.1007/978-3-319-54784-8

Loidi, J., Fernández-González, F. (2012). Potential natural vegetation: reburying or reboring?. Journal of Vegetation Science, 23(3), 596-604.

Nef, A. (2011). Conquérir et gouverner la Sicile islamique aux XIe et XIIe siècles. Rome: École française de Rome.

Papanastasis, V. P., Kyriakakis, S., \& Kazakis, G. (2002). Plant diversity in relation to overgrazing and burning in mountain Mediterranean ecosystems. Journal of Mediterranean Ecology, 3, 53-64. Retrieved from http://www.jmecology.com/wp-content/uploads/2014/03/06papanastasis.pdf

Podani, J. (2006). Braun-Blanquet's legacy and data analysis in vegetation science. Journal of Vegetation Science, 17,113-117. doi:10.1111/j.16541103.2006.tb02429.x

Posluschny, A. G. (2009). Over the hills and far away? -Cost surface based models of prehistoric settlement hinterlands. In B. Frischer, J. Webb Crawford, \& D. Koller (Eds.). Making History Interactive. Proceedings of the 37th International Conference of Computer Applications and Quantitative Methods in Archaeology 
(pp. 313-319), Oxford: BAR. Retrieved from

http://proceedings.caaconference.org/files/2009/38_Posluschny_CAA2009.pdf

Rivas-Martínez, S. (2005). Avances en Geobotánica. Discurso de Apertura del Curso Académico de la Real Academia Nacional de Farmacia de año 2005 [Advances in Geobotany. Opening speech of the Academic Course of the Royal National Academy of Pharmacy of the year 2005], Madrid. Retrieved from http://www.globalbioclimatics.org/book/ranf2005.pdf

Rivas-Martinez, S. (Ed.). (2007). Mapa de series, geoseries y geopermaseries de vegetación de Espana [Map of series, geoseries and geopermaseries of vegetation in Spain]. Itinera Geobotanica, 17, 5-436. Retrieved from http://digital.csic.es/handle/10261/108186

Roper, D. C. (1979). The method and theory of site catchment analysis: a review. Advances in archaeological method and theory, 2, 119-140.

Rotolo, A. (2016). The Trodden Path: GIS-analyses of Settlement and Mobility Patterns in Western Sicily during the Islamic Period. Journal of Islamic Archaeology, 3(1), 109-136. doi: 10.1558/jia.v3i1.31875

Surface-Evans, S. (2012). Cost catchments: A least cost application for modeling Hunter-Gatherer land use. In D.A. White \& S. Surface-Evans (Eds.), Least Cost Analysis of Social Landscapes (pp. 128-151), Salt Lake City: University of Utah Press. Retrieved from http://cdmbuntu.lib.utah.edu/cdm/ref/collection/upcat/id/1817

Tobler, W. (1993). Three Presentations on Geographical Analysis and Modeling: NonIsotropic Geographic Modeling; Speculations on the Geometry of Geography; and Global Spatial Analysis; Technical Report. Santa Barbara: National Center 
for Geographic Information and Analysis. Retrieved from http://escholarship.org/uc/item/05r820mz

Tripcevich, N. (2006). Anisotropic Cost Surfaces and Least-Cost Paths [weekly inClass exercises for course of GIS in Anthropology]. Retrieved from http://www.mapaspects.org/courses/gis-and-anthropology/weekly-classexercises/week-9-anisotropic-cost-surfaces-and-least-cost-.

Van Leusen, P. M. (2002). Pattern to Process: Methodological Investigations into the Formation and Interpretation of Spatial Patterns in Archaeological Landscapes (Unpublished doctoral dissertation), Rijksuniversiteit Groningen. Retrieved from http://dissertations.ub.rug.nl/faculties/arts/2002/p.m.van.leusen/.

Vita-Finzi, C. \& Higgs, E. S. (1970). Prehistoric economy in the Mount Carmel area of Palestine. Site catchment analysis. Proceedings of the Prehistoric Society, 36. 137. doi: 10.1017/S0079497X00013074

Table 1. Percentage of the surface covered by different vegetation series inside the catchment area walkable in $0.5 \mathrm{~h}$ and $1 \mathrm{~h}$ for each site. Sites numbered from 1 to 25 for the case study area of Corleone and from 26 to 35 for the control area of Contessa Entellina.

Figure 1. Schematic illustration of the plant succession in the holm oak woods vegetation series (A) and downy oak vegetation series (B). Forestry and fire modify the structure of the primary holm oak forest (A1) into a coppice woodland (A2); the development of pastoralism represents another factor of environmental change: transforming the coppice woodlands (A3) into shrublands and grasslands (A4); When a substantial morphological change occurs (e.g. the construction of terraces) the landscape can be used for agricultural activities (A5); the abandonment of the cultivated 
terraces produces a resilience process of the natural vegetation slowed by pastoral activities. Depending on the intensity of the exploitation and fire, the primary downy oak forest (B1) can become a coppice woodland (B2), or an agricultural spaces (B4), or - less frequently - a shrubland used for grazing (B3). The shrubland can be also a consequence of the abandonment of cultivated fields (Reworked from Bazan et al. 2018).

Figure 2. Case study area (Corleone) and control area (Contessa Entellina) in centralwestern Sicily.

Figure 3. The holm oak forest and grassland on the western slopes of Mt. Barraù.

Figure 4. The agricultural landscape of the Castro/Giardinello valley.

Figure 5. Flowchart of work phases to create the vegetation series map.

Figure 6. Map of vegetation series of the Castro/Giardinello valley and Mt Barraù area.

Figure 7. Archaeological sites and vegetation series in the case study area of Corleone (A) and the control area of Contessa Entellina (B).

Figure 8. Example of the relationship between the site catchment based on $0.5 \mathrm{~h}$ and $1 \mathrm{~h}$ walking areas and the vegetation series (Site n. 5 and Site n. 16).

Figure 9. Cluster dendrogram of site-catchment area based on the coverage of vegetation series. 


\begin{tabular}{|c|c|c|c|c|c|c|c|c|c|c|c|}
\hline \multicolumn{10}{|c|}{ Vegetation series (\%) } & \multirow{2}{*}{\multicolumn{2}{|c|}{$\begin{array}{c}\text { Catchment area } \\
\text { total surface } \\
\text { [ha] }\end{array}$}} \\
\hline \multirow{2}{*}{$\begin{array}{c}\text { Site } \\
\text { ID }\end{array}$} & \multirow{2}{*}{\begin{tabular}{|l|} 
Typology / Walking time \\
\end{tabular}} & \multicolumn{2}{|c|}{$\begin{array}{l}\text { Ampelodesmo }-Q \text {. } \\
\text { ilicis sigmetum }\end{array}$} & \multicolumn{2}{|c|}{$\begin{array}{l}\text { Oleo }-Q \text {. virgilianae } \\
\text { sigmetum }\end{array}$} & \multicolumn{2}{|c|}{$\begin{array}{l}\text { Sorbo-Q. ilicis } \\
\text { sigmetum }\end{array}$} & \multicolumn{2}{|c|}{$\begin{array}{l}\text { Sorbo-Q.virgilianae } \\
\text { sigmetum }\end{array}$} & & \\
\hline & & $0,5 \mathrm{~h}$ & $1 \mathrm{~h}$ & $0,5 \mathrm{~h}$ & $1 \mathrm{~h}$ & $0,5 \mathrm{~h}$ & $1 \mathrm{~h}$ & $0,5 \mathrm{~h}$ & $1 \mathrm{~h}$ & $0,5 \mathrm{~h}$ & $1 \mathrm{~h}$ \\
\hline 1 & Settlement_Medieval & 3,4 & 10,5 & 96,6 & 89,5 & - & - & - & - & 170,36 & 564,34 \\
\hline 2 & Settlement_Medieval & 3,7 & 10,3 & 96,3 & 89,7 & - & - & - & - & 165,94 & 553,65 \\
\hline 3 & Settlement_Medieval & 3,5 & 9,9 & 96,5 & 90,1 & - & - & - & - & 166,40 & 545,90 \\
\hline 4 & Settlement_Medieval & 3,6 & 10,4 & 96,4 & 89,6 & - & - & - & - & 312,59 & 551,71 \\
\hline 5 & Settlement_Medieval & 11,0 & 9,1 & 89,0 & 90,9 & - & - & - & - & 108,79 & 435,89 \\
\hline 6 & Settlement_Protohistoric & 14,3 & 9,5 & 85,7 & 90,5 & - & - & - & - & 97,67 & 422,78 \\
\hline 7 & Settlement_Protohistoric & 6,9 & 8,9 & 93,1 & 91,1 & - & - & - & - & 133,09 & 493,01 \\
\hline 8 & Settlement_Protohistoric & 7,0 & 9,4 & 93,0 & 90,6 & - & - & - & - & 133,03 & 490,06 \\
\hline 9 & Settlement_Protohistoric & 4,4 & 10,2 & 95,6 & 89,8 & - & - & - & - & 136,36 & 501,84 \\
\hline 10 & Shepherds structures_Modern & 5,3 & 10,1 & 94,7 & 89,9 & - & - & - & - & 132,76 & 490,52 \\
\hline 11 & Settlement_Modern & 5,3 & 9,2 & 94,7 & 90,8 & - & - & - & - & 152,93 & 439,45 \\
\hline 12 & Shepherds structures_Modern & 3,4 & 8,8 & 96,6 & 91,2 & - & - & - & - & 164,01 & 487,29 \\
\hline 13 & Shepherds structures_Modern & 25,3 & 31,3 & 74,7 & 68,7 & - & - & - & - & 74,37 & 316,06 \\
\hline 14 & Shepherds structures_Modern & 26,1 & 33,2 & 73,9 & 66,8 & - & - & - & - & 86,01 & 305,38 \\
\hline 15 & Shepherds structures_Modern & 38,6 & 38,1 & 61,4 & 61,9 & - & - & - & - & 62,67 & 239,51 \\
\hline 16 & Settlement_Classical & 26,2 & 28,3 & 73,8 & 71,7 & - & - & - & - & 60,82 & 309,81 \\
\hline 17 & Settlement_Modern & 1,1 & 9,9 & 31,4 & 35,9 & 2,7 & 1,8 & 64,8 & 52,3 & 119,37 & 283,81 \\
\hline 18 & Shepherds structures_Modern & 0,2 & 9,8 & - & 17,5 & 2,2 & 2,1 & 97,6 & 70,6 & 77,86 & 84,70 \\
\hline 19 & Shepherds structures_Modern & 18,2 & 20,1 & 81,8 & 79,9 & - & - & - & - & 96,68 & 388,79 \\
\hline 20 & Shepherds structures_Modern & 27,5 & 41,8 & 72,5 & 58,2 & - & - & - & - & 70,41 & 177,24 \\
\hline 21 & Settlement_Modern & 2,9 & 8,5 & 97,1 & 91,5 & - & - & - & - & 343,81 & 622,88 \\
\hline 22 & Settlement_Modern & 3,3 & 4,3 & 96,7 & 95,7 & - & - & - & - & 140,51 & 366,45 \\
\hline 23 & Shepherds structures_Modern & 4,3 & 7,8 & 70,9 & 49,1 & 0,5 & 1,7 & 24,3 & 41,4 & 133,66 & 273,90 \\
\hline 24 & Shepherds structures_Modern & 34,4 & 30,2 & 65,6 & 69,8 & - & - & - & - & 40,14 & 110,41 \\
\hline 25 & Settlement_Modern & 1,2 & 9,9 & 98,8 & 90,1 & - & - & - & - & 89,90 & 289,16 \\
\hline 26 & Prehistoric site & 0,4 & 0,6 & 99,6 & 99,4 & - & - & - & - & 203,66 & 518,08 \\
\hline 27 & Prehistoric site & 0,2 & 1,6 & 99,8 & 98,4 & - & - & - & - & 203,67 & 720,87 \\
\hline 28 & Prehistoric_Medieval site & 4,1 & 0,9 & 95,9 & 99,1 & - & - & - & - & 150,98 & 454,62 \\
\hline 29 & Late Archaic_Classical_Hellenistic site & 0,3 & 0,6 & 99,7 & 99,4 & - & - & - & - & 104,03 & 394,22 \\
\hline 30 & Late Archaic_Classical_Hellenistic site & 1,9 & 4,0 & 98,1 & 96,0 & - & - & - & - & 156,03 & 603,25 \\
\hline 31 & $\begin{array}{l}\text { Late Archaic_Classical_Hellenistic_Medieval } \\
\text { site }\end{array}$ & 0,0 & 1,1 & 100,0 & 98,9 & - & - & - & - & 145,90 & 592,09 \\
\hline 32 & Medieval site & 28,6 & 14,2 & 71,4 & 85,8 & - & - & - & - & 53,07 & 240,92 \\
\hline 33 & Late Archaic_Classical site & 39,9 & 15,4 & 60,1 & 84,6 & - & - & - & - & 67,55 & 235,70 \\
\hline 34 & Late Archaic_Classical_Hellenistic site & 7,3 & 8,9 & 92,7 & 91,1 & - & - & - & - & 260,35 & 542,15 \\
\hline 35 & Medieval site & 0,7 & 0,7 & 99,3 & 99,3 & - & - & - & - & 122,86 & 436,31 \\
\hline
\end{tabular}




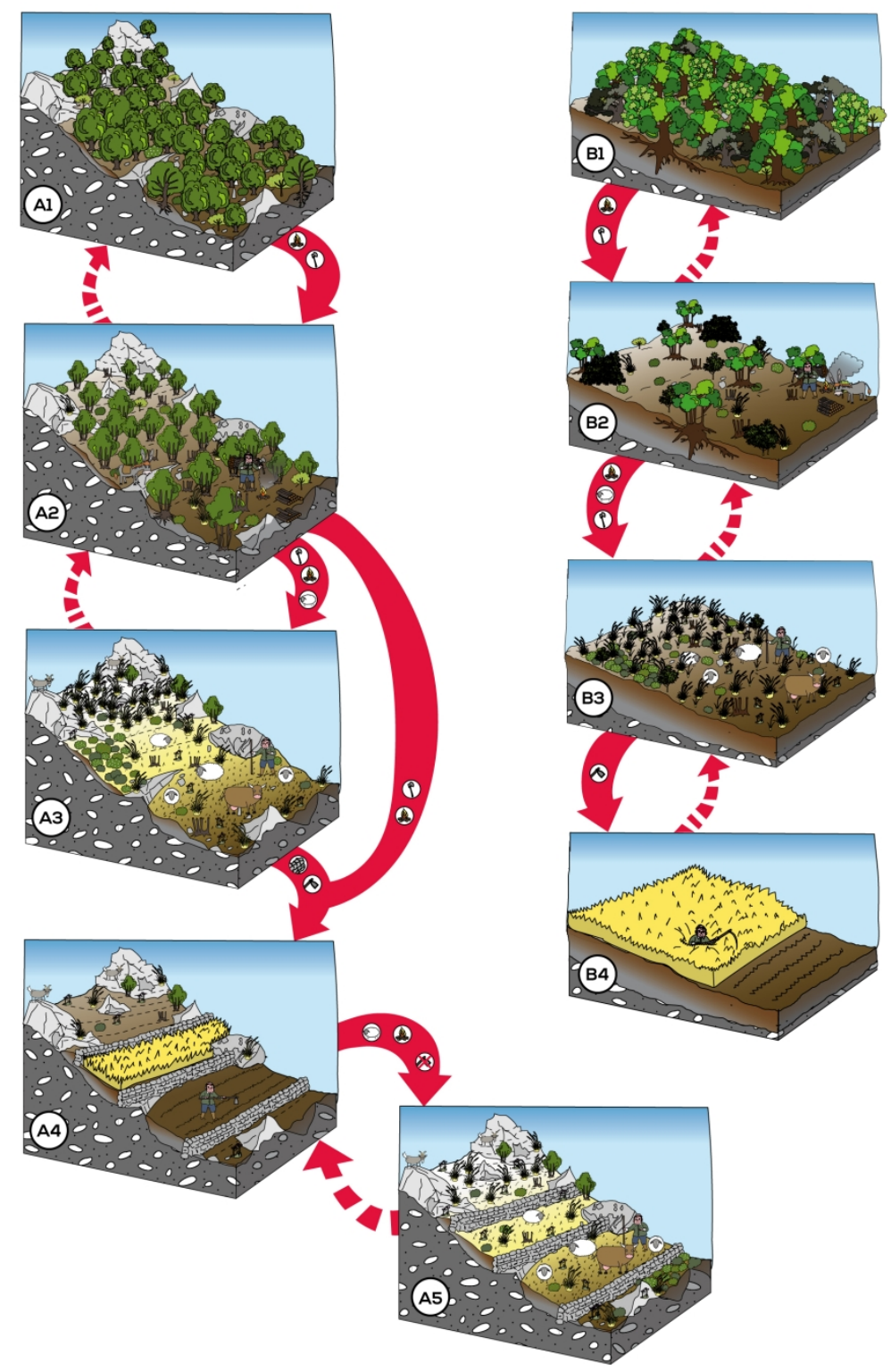

Figure 1. Schematic illustration of the plant succession in the holm oak woods vegetation series $(A)$ and downy oak vegetation series $(B)$. Forestry and fire modify the structure of the primary holm oak forest (A1) into a coppice woodland ( $A 2)$; the development of pastoralism represents another factor of environmental change: transforming the coppice woodlands (A3) into shrublands and grasslands (A4); When a substantial morphological change occurs (e.g. the construction of terraces) the landscape can be used for agricultural activities (A5); the abandonment of the cultivated terraces produces a resilience process of the natural vegetation slowed by pastoral activities. Depending on the intensity of the exploitation and fire, the primary downy oak forest (B1) can become a coppice woodland (B2), or an agricultural spaces (B4), or - less frequently - a shrubland used for grazing (B3). The shrubland can be also a consequence of the abandonment of cultivated fields.

$170 \times 240 \mathrm{~mm}(300 \times 300 \mathrm{DPI})$ 


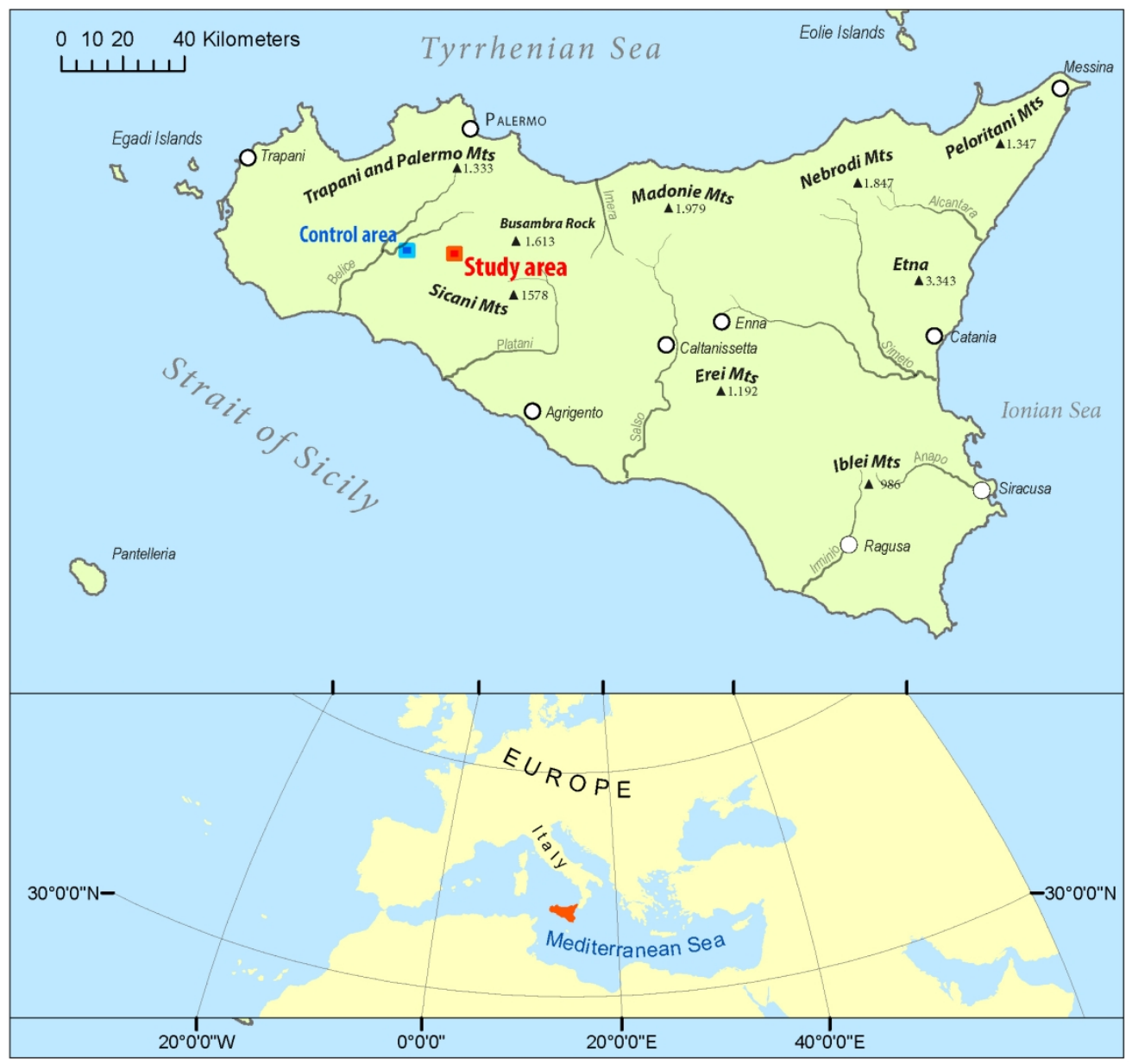

Figure 2. Case study area (Corleone) and control area (Contessa Entellina) in central-western Sicily.

$171 \times 161 \mathrm{~mm}(300 \times 300 \mathrm{DPI})$ 


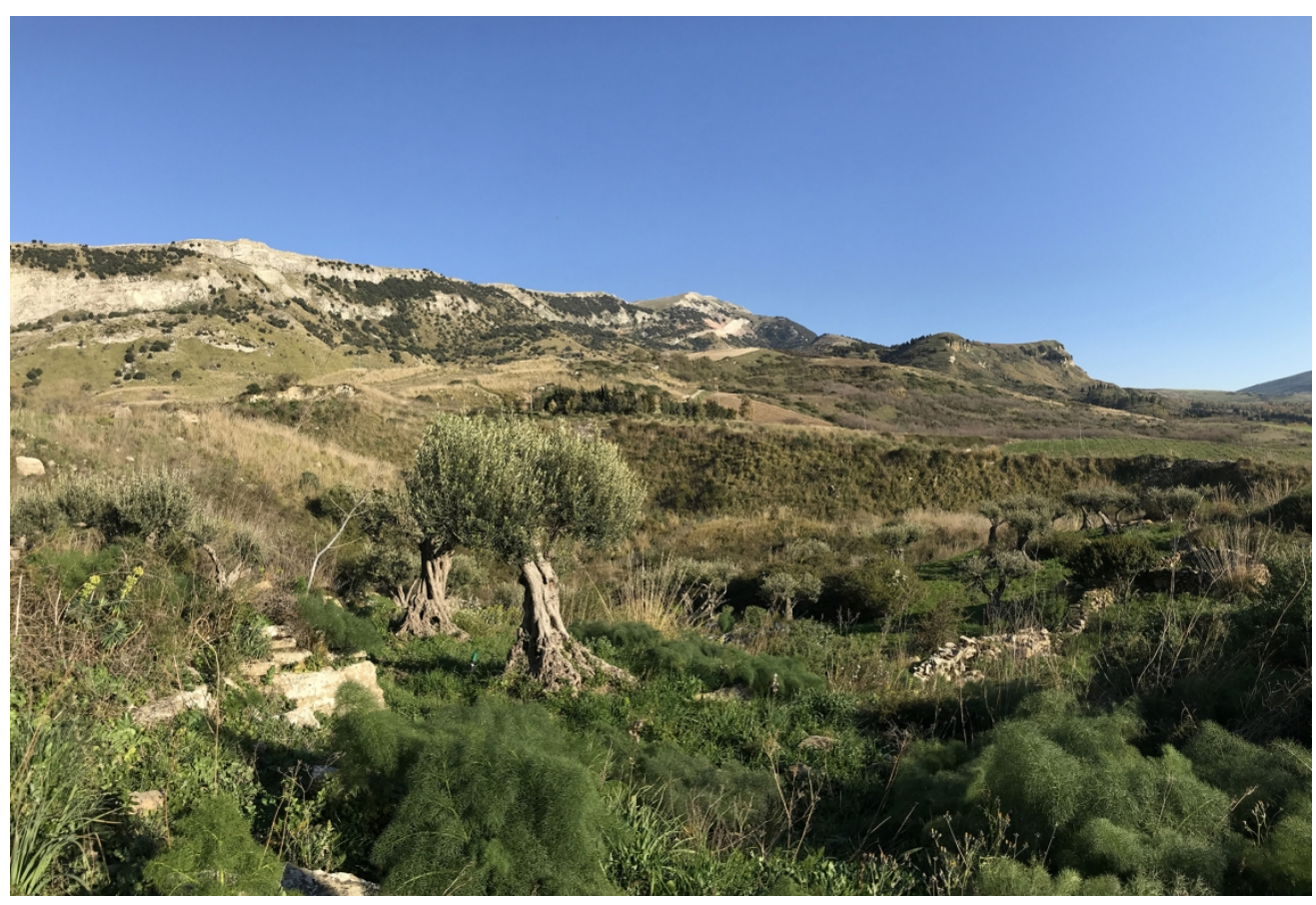

Figure 3. The holm oak forest and grassland on the western slopes of Mt. Barraù. $175 \times 118 \mathrm{~mm}(300 \times 300$ DPI) 


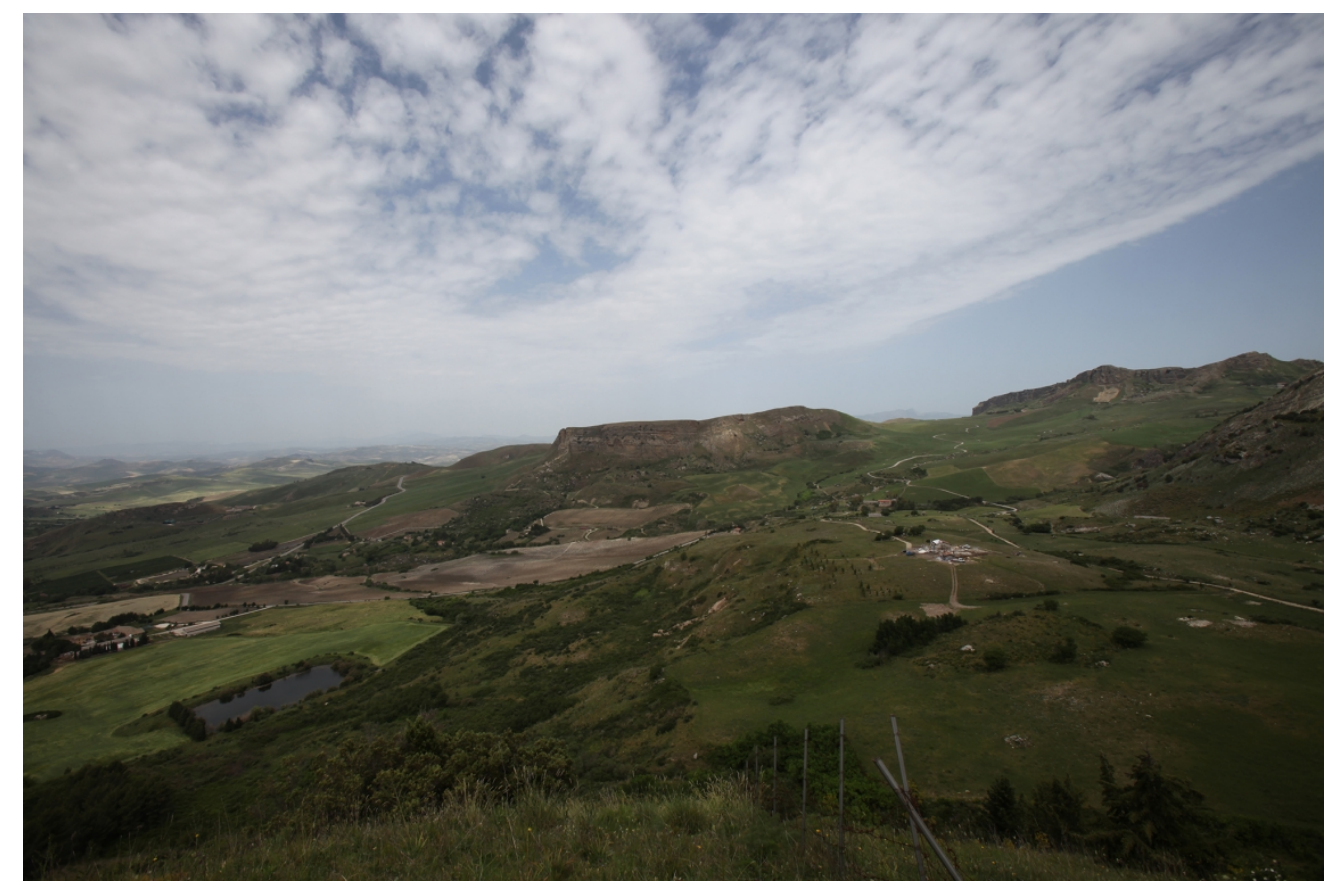

Figure 4. The agricultural landscape of the Castro/Giardinello valley. $170 \times 113 \mathrm{~mm}(300 \times 300 \mathrm{DPI})$ 


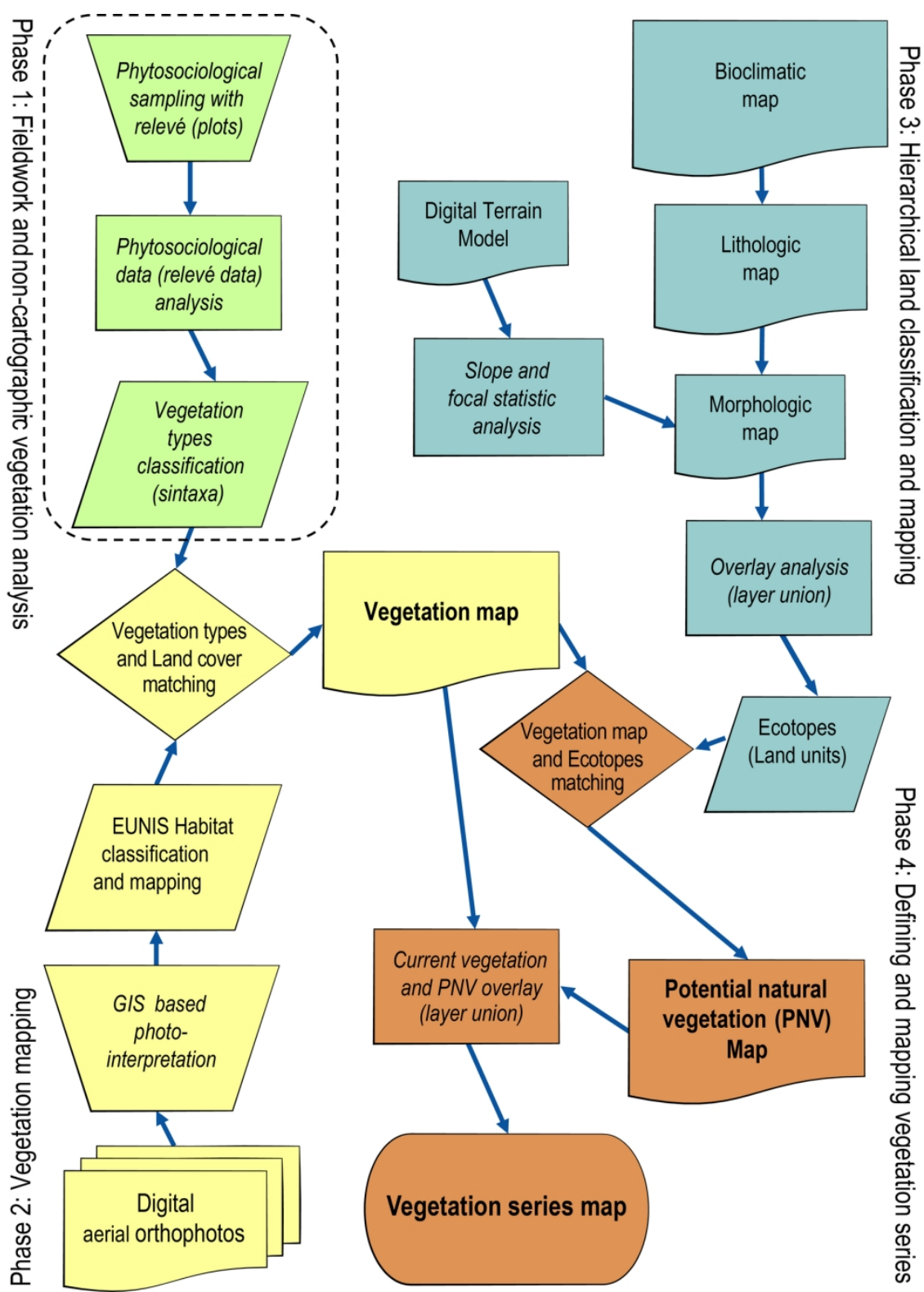

Figure 5. Flowchart of work phases to create the vegetation series map.

$140 \times 194 \mathrm{~mm}(300 \times 300 \mathrm{DPI})$ 

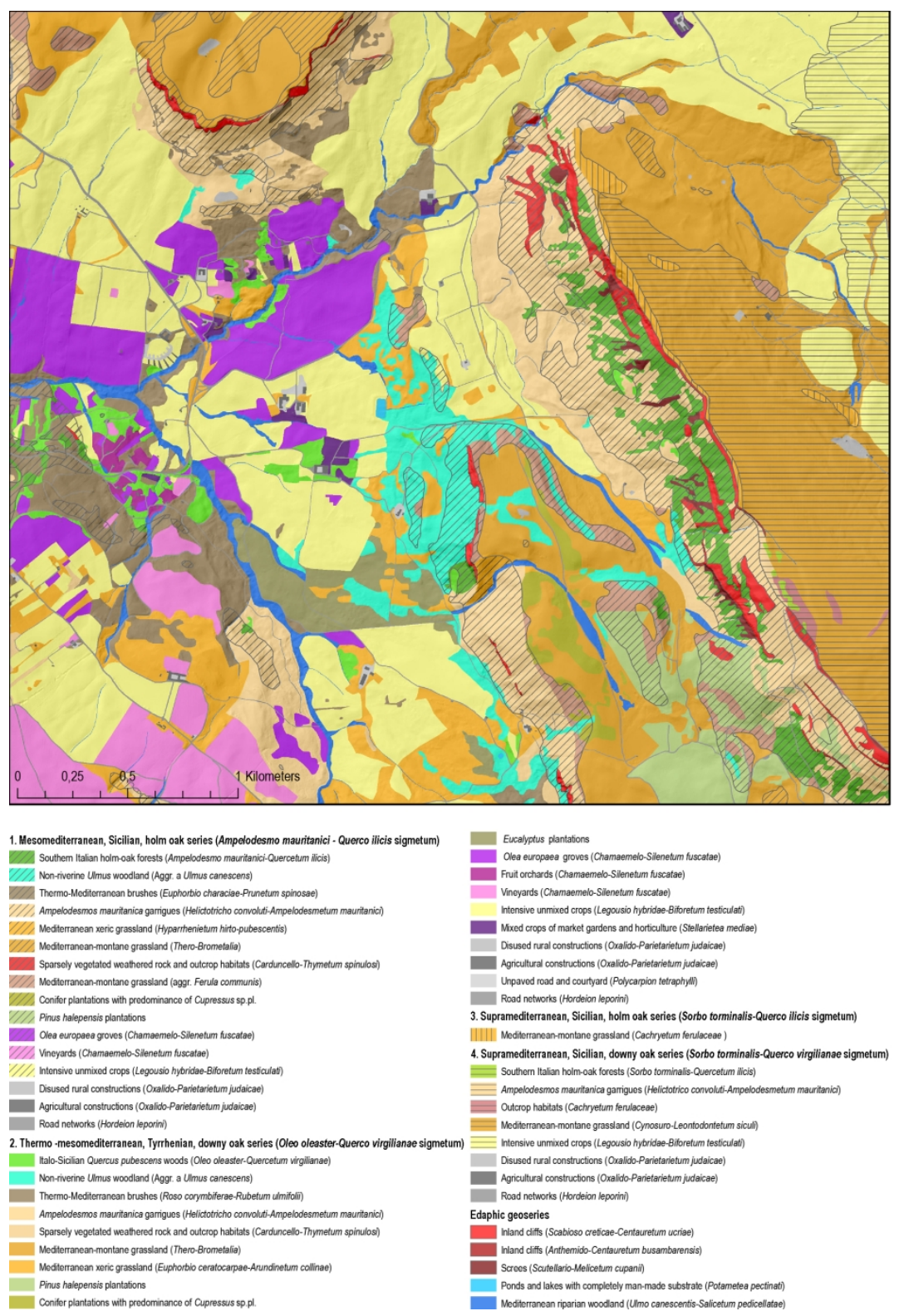

Figure 6. Map of vegetation series of the Castro/Giardinello valley and Mt Barraù area. $178 \times 262 \mathrm{~mm}(300 \times 300 \mathrm{DPI})$ 


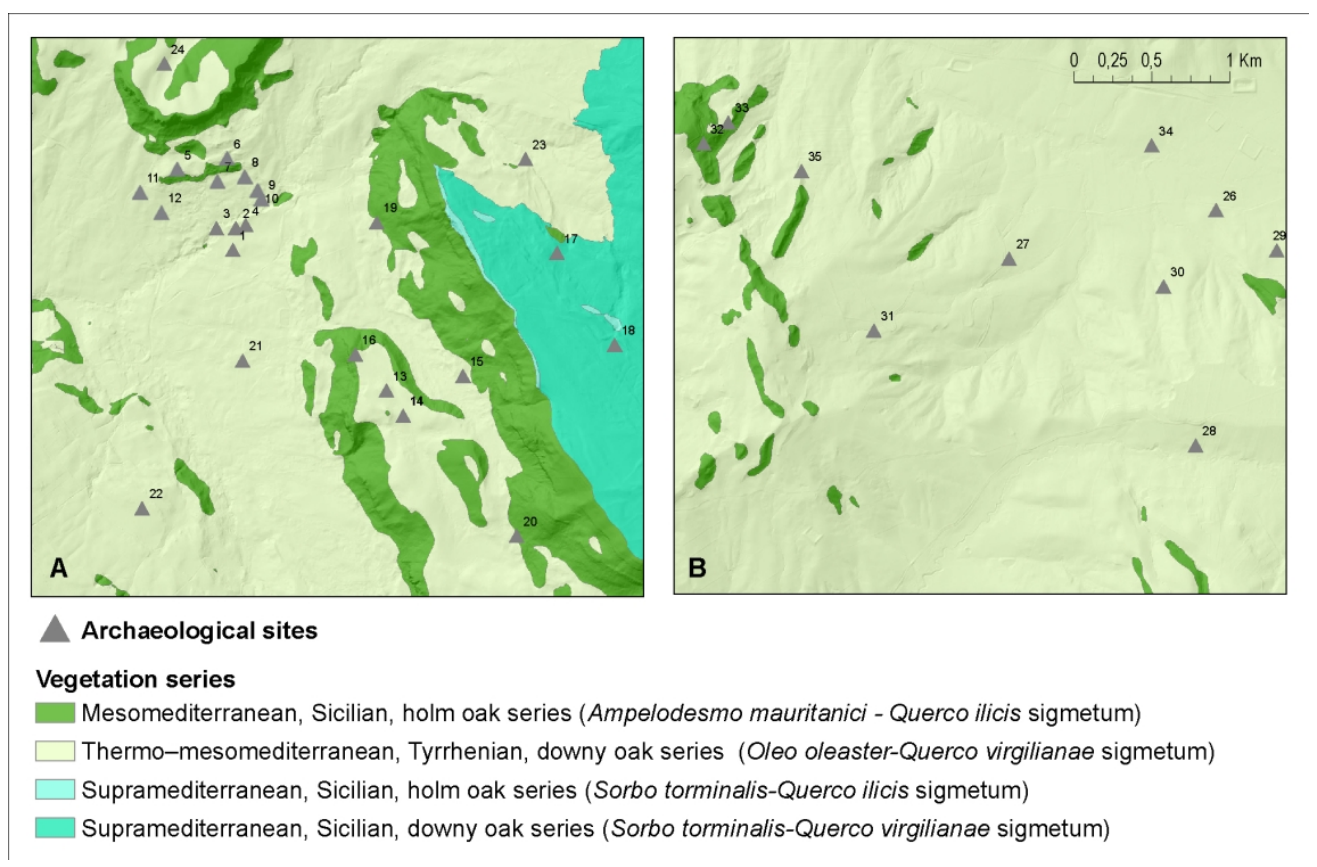

Figure 7. Archaeological sites and vegetation series in the case study area of Corleone (A) and the control area of Contessa Entellina (B).

\section{$170 \times 110 \mathrm{~mm}(300 \times 300 \mathrm{DPI})$}




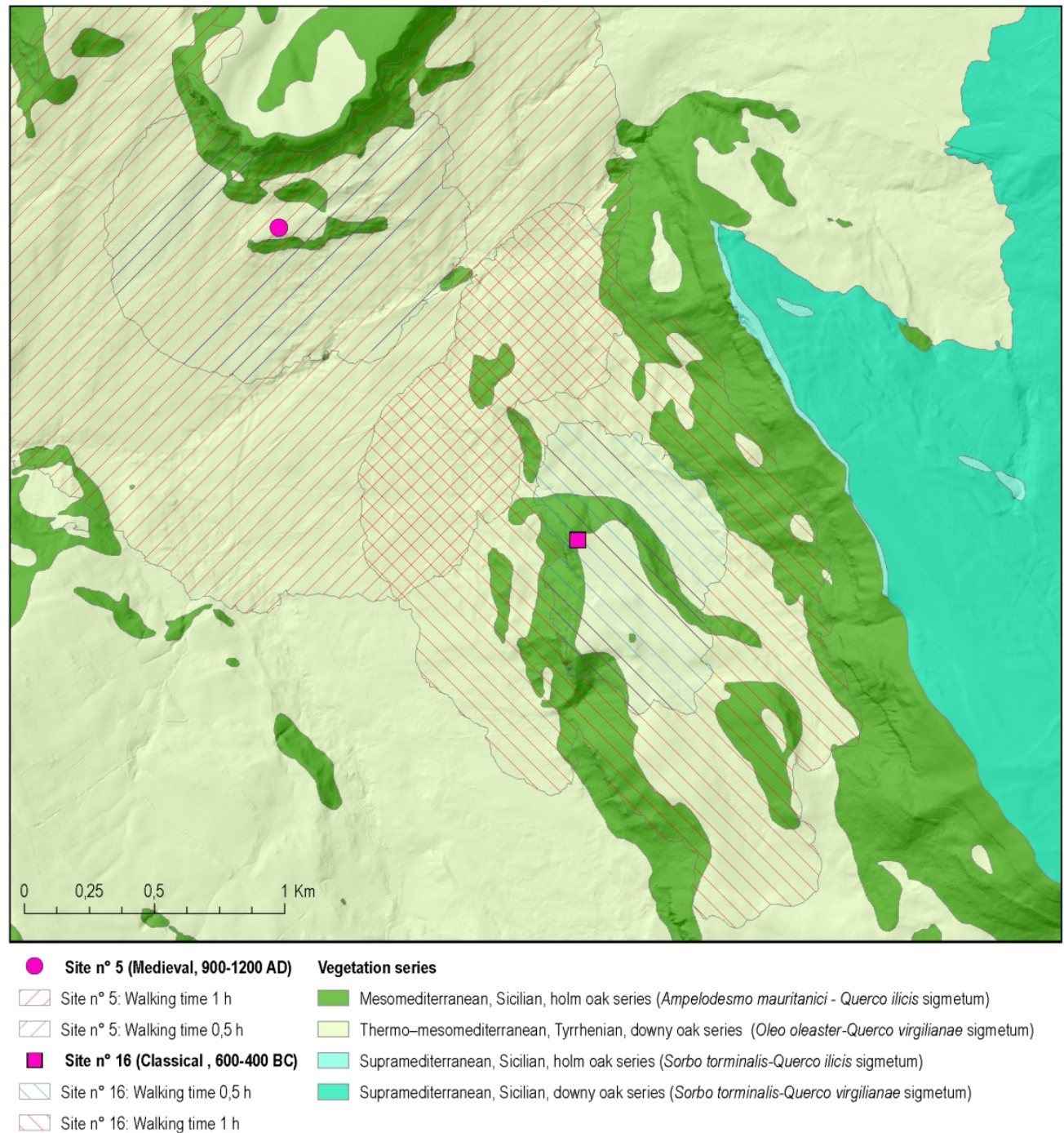

Figure 8. Example of the relationship between the site catchment based on $0.5 \mathrm{~h}$ and $1 \mathrm{~h}$ walking areas and the vegetation series (Site n. 5 and Site n. 16).

$170 \times 182 \mathrm{~mm}(300 \times 300 \mathrm{DPI})$ 


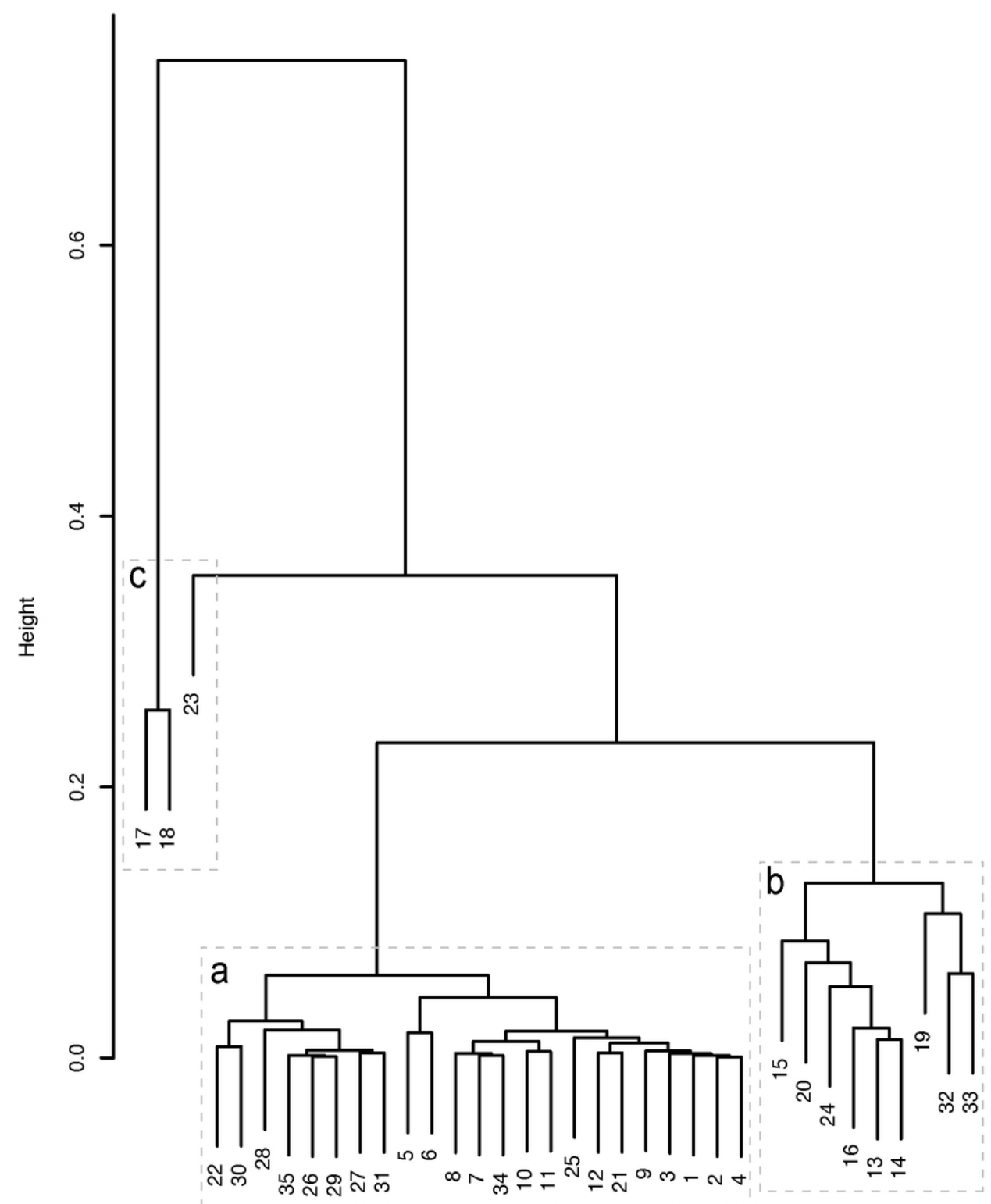

Figure 9. Cluster dendrogram of site-catchment area based on the coverage of vegetation series. $80 \times 99 \mathrm{~mm}(300 \times 300 \mathrm{DPI})$ 